\title{
Keefektifan Model Saintifik (Scientific) Terhadap Kemampuan Membaca Intensif
}

\author{
*Neni Shofiani
}

Pendidikan Guru Sekolah Dasar, Universitas PGRI Semarang, Indonesia

\author{
A R T I C L E I N F O \\ Article history: \\ Received 10 November \\ 2018 \\ Received in revised form \\ 09 December 2018 \\ Accepted 15 January 2019 \\ Available online 25 \\ February 2019 \\ Kata Kunci: \\ efektif, membaca intensif, \\ saintifik \\ Keywords: \\ efectivity, intensive reading \\ scientific
}

\begin{abstract}
A B S T R A K
Tujuan dalam penelitian adalah untuk mengetahui keefektifan model pembelajaran Saintifik terhadap kemampuan membaca intensif siswa kelas $\mathrm{V}$. Jenis penelitian ini adalah penelitian kuantitatif dalam bentuk Pre-Eksperimental Design dengan One- Group Pretest-Posttest Design. Data dalam penelitian ini di peroleh melalui observasi, angket.dan dokumentasi. Hasil analisis angket hasil belajar siswa sebelum dan setelah diberi perlakuan menggunakan model pembelajaran Saintifik mengalami peningkatan. Berdasarkan hasil uji-t dketahui $>$ atau $9,0507>2,021$. kesimpulannya model saintifik terbukti efektif terhadap kemampuan membaca intensif siswa.
\end{abstract}

\section{A B S T R A C T}

The purpose of the study was to determine the effectiveness of the Scientific learning model on intensive reading skills of class $V$ students. This type of research is quantitative research in the form of PreExperimental Design with One-Group Pretest-Posttest Design. The data in this study were obtained through observation, questionnaire and documentation. The results of the student learning outcomes questionnaire analysis before and after being treated using the Scientific learning model increased. Based on the results of the $t$-test know $t$ count $>t$ table or 9,0507 > 2.021. in conclusion, the scientific model proved effective for students' intensive reading skills.

\section{Pendahuluan}

Bahasa Indonesia memegang peran utama dalam kehidupan. baik dalam pendidikan, sosial, budaya dan perkembangan Intelektual. Seperti yang dinyatakan dalam Standar Kompetensi Dasar Tingkat SD/MI dalam Peraturan Menteri Pendidikan Nasional Nomor 22 Tahun 2006 tentang Standar Isi untuk Satuan Pendidikan Dasar dan Menengah bahwa Bahasa memiliki peran sentral dalam perkembangan intelektual, sosial, dan emosional peserta didik dan merupakan penunjang keberhasilan dalam mempelajari semua bidang studi(Kemendikbud, 2003). Membaca merupakan salah satu jenis kemampuan berbahasa tulis yang bersifat reseptif. Disebut reseptif karena dengan membaca seseorang akan memperoleh informasi, ilmu pengetahuan, dan pengalaman-pengalaman baru. Semua yang diperoleh melalui bacaan itu akan memungkinkan orang tersebut mampu mempertinggi daya pikirannya, mempertajam pandangannya, dan memperluas wawasannya. Oleh karena itu, pembelajaran membaca di sekolah mempunyai peranan yang penting. Dalam pembelajaran membaca, guru dapat memilih wacana-wacana yang berkaitan dengan tokoh nasional, kepahlawanan, kenusantaraan, dan kepariwisataan.S elain itu melalui contoh pembelajaran membaca, guru dapat mengembangkan nilai-nilai moral, kemampuan bernalar,dan kreativitas anak didik(Irdawati, Yunidar, \& Darmawan, 2012). Membaca merupakan keterampilan berharga dapat digunakan sepanjang hidup. Membaca yang baik ditunjukkan dengan kemampuan seseorang menyelesaikan tugas membaca dengan mudah dan cepat disertai peningkatan pemahaman sehingga memperoleh nilai lebih baik dan belajar dengan cepat. Hal tersebut berdampak pada kemampuan menyelesaikan sekolah dan menjalani hidup lebih mudah(Khasanah \& Isah Cahyani, 2016).

Copyright (c) Universitas Pendidikan Ganesha. All rights reserved. 
Hal tersebut berdampak pada kemampuan menyelesaikan sekolah dan menjalani hidup lebih mudah (DePoter, 2003)

(Suyitno \& Ngatmini, 2018) bahasa merupakan sarana komunikasi bagi masyarakat penuturnya. Agar dapat berkomunikasi secara efektif, penutur perlu memahami sejarah, kedudukan dan fungsi, serta keberadaan sarana komunikasi tersebut. Memahami bahasa Indonesia sebagai sarana komunikasi, berarti perlu memahami pula (1) sejarah lahir, (2) kedudukan dan fungsi, serta (3) pembinaan dan pengembangan bahasa Indonesia. Bahasa Indonesia merupakan bahasa yang sangat penting untuk digunakan dalam kehidupan sehari-hari, sebagai salah satu sarana komunikasi antar manusia dari berbagai daerah, budaya daerah dan bangsa. Bahasa sebagai alat komunikasi baik dalam kategori nasional maupun internasional dari yang formal sampai dengan yang non formal, dan baik lisan maupun tulis maka dari itu bahasa Indonesia harus diajarkan kepada anak sedini mungkin.

(Tarigan, 2017) mengemukakan bahwa keterampilan berbahasa (language arts, language skills) dalam kurikulum di sekolah biasanya mencakup empat segi: (1) keterampilan menyimak/ mendengarkan (listening skills); (2) keterampilan berbicara (speaking skills); (3) keterampilan membaca (reading skills); (4) keterampilan menulis (writing skills). Keempat keterampilan tersebut pada dasarnya merupakan satu kesatuan, merupakan catur-tunggal (Dawson (Tarigan, 2017)). Menurut (Resmini \& Juanda, 2007) "membaca pemahaman atau reading for understanding adalah salah satu bentuk kegiatan membaca dengan tujuan utama untuk memahami isi pesan yang terdapat dalam bacaan. Membaca pemahaman lebih menekankan pada penguasaan isi bacaan, bukan pada indah, cepat atau lambatnya membaca." Abidin (2012) mengemukakan bahwa "pembelajaran membaca dapat diartikan sebagai serangkaian aktivitas yang dilakukan siswa untuk mencapai keterampilan membaca." Selanjutnya dijelaskan pula bahwa pembelajaran membaca tidak semata-mata dilakukan agar siswa mampu membaca, tetapi juga merupakan sebuah proses yang melibatkan seluruh aktivitas mental dan berpikir siswa dalam memahami, mengritisi, dan mereproduksi sebuah wacana tertulis. Menurutnya aktivitas yang dapat dilakukan siswa sangat beragam bergantung pada strategi membaca yang diterapkan guru dalam pembelajaran.

Perkembangan ilmu pengetahuan dan teknologi menuntut seseorang untuk memiliki pengetahuan seluas-luasnya. Untuk itu, keterampilan membaca sebagai salah satu keterampilan berbahasa penting untuk diajarkan kepada anak sebaik mungkin guna menciptakan suatu generasi bangsa yang dapat memperoleh pengetahuan baru yang disampaikan melalui tulisan dengan membaca. Perkembangan ilmu pengetahuan dan teknologi menuntut terciptanya masyarakat yang gemar belajar. Proses belajar yang efektif antara lain dilakukan melalui membaca (Munggaran, 2014). Masyarakat yang gemar membaca memperoleh pengetahuan dan wawasan baru yang akan semakin meningkatkan kecerdasannya sehingga mereka lebih mampu menjawab tantangan hidup pada masa-masa mendatang (Rahim, 2015)

Menurut Nuttal, membaca dapat bermakna salah satu atau lebih dari sejumlah aktivitas: mengkodekan, menerjemahkan, mengidentifikasikan, berbicara, melafalkan, mengerti, memberikan reaksi, memberi arti membaca sebagai proses berpikir, proses rasionalisasi atas apa yang dibaca, mengandung pola pola berpikir, aturan dan hukum, analisa, sebab akibat, pemecahan masalah, dan bukan sekedar pengenalan rumus atau lambang tertulis dan memahami maknanya(Erlina, 2013). Keterampilan Membaca merupakan suatu pembelajaran yang menyangkut di setiap mata pelajaran, namun banyak siswa yang tidak suka dengan membaca. Menurutnya membaca adalah kegiatan yang membosankan. dan tidak adanya suatu kreatifitas pengajar dalam pembelajaran khususnya membaca. Keterampilan membaca memiliki peran penting dalam peningkatan mutu pendidikan, khususnya dalam menghasilkan siswa yang berkualitas. Membaca juga merupakan suatu pengetahuan yang sangat mendasar dan penting bagi kehidupan sehari-hari karena setiap manusia pasti akan bertemu dan berhubungan dengan membaca baik itu membaca formal maupun non formal. Membaca Intensif merupakan suatu kegiatan membaca untuk memahami isi bacaan secara terperinci dan untuk mengingat isi bacaan tersebut. Hal ini sesuai dengan apa yang dinyatakan (Tarigan, 2017) Tujuan utama membaca intensif adalah untuk memperoleh sukses dalam pemahaman penuh terhadap argumen-argumen yang logis, urutan-urutan retoris atau pola-pola teks, pola-pola simbolisnya; nada-nada tambahan yang bersifat emosional dan sosial, pola-pola sikap dan tujuan sang pengarang, dan juga sarana-sarana linguistik yang dipergunakan untuk mencapai tujuan.

Pentingnya keterampilan membaca intensif pada siswa kelas $\mathrm{V}$ yaitu untuk mengetahui permasalahan siswa di dalam kelas terutama pada saat pelajaran membaca. Pembelajaran membaca masih terjadi berbagai masalah. Banyak siswa di SD yang kurang berminat terhadap materi keterampilan membaca intensif karena rata-rata siswa bosan dengan membaca. Dengan demikian, pembelajaran membaca intensif memiliki peran penting bagi anak. Anak akan lebih mudah mendapatkan pengetahuan dengan membaca intensif terutama untuk menyerap dan mendapatkan pengetahuan yang ada. Andartiani (2018) menyatakan bahwa apabila tidak memiliki kemampuan tersebut, maka seseorang akan kesulitan untuk menambah pengetahuan dan pengalamannya serta kesulitan untuk mengikuti perkembangan yang 
ada. Memahami pentingnya keterampilan membaca yang harus dimiliki siswa, berdasarkan observasi di Kelas V, masih terdapat masalah bahwa kemampuan membaca siswa kurang maksimal. siswa masih kesulitan dalam memahami isi bacaan dari teks yang telah dibacanya, hasil belajar siswa dalam pembelajaran Bahasa Indonesia masih di bawah Kriteria Ketuntasan Minimal (KKM). Dan model yang digunakan guru kurang mendorong siswa untuk aktif bertanya tentang materi yang dipelajari sehingga mengakibatkan siswa kurang antusias dalam belajar. Maka dalam pembelajaran Bahasa Indonesia di perlukan langkah-langkah sistematis yakni dengan menggunakan model yang cocok agar siswa dapat berpikir logis, kritis, dan inovatif serta dapat menciptakan suasana pembelajaran yang menyenangkan.

Untuk mengatasi masalah tersebut guru harus bisa membuat suasana pembelajaran membaca intensif lebih menyenangkan dan meibatkan siswa agar termotivasi dalam mengikuti pembelajaran. Dalam pembelajaran ini, peneliti sebagai fasilitator dan mediator yang harus bisa mengelola pembelajaran di kelas dengan baik. Salah satunya yaitu dalam pemilihan dan penggunaan model pembelajaran yang inovatif dalam setiap pembelajarannya. Oleh karena itu, untuk meningkatkan kemampuan membaca intensif peneliti menggunakan Model Saintifik. Penggunanaan Model Saintifik disini dimaksudkan agar dapat mempermudah pengusaan keterampilan berbahasa, khususnya keterampilan membaca intensif bahasa indonesia.

Menurut (Sani, 2014) tahapan aktivitas belajar yang dilakukan dengan pembelajaran saintifik tidak harus dilakukan mengikuti prosedur yang kaku, namun dapat disesuaikan dengan pengetahuan yang hendak dipelajari. Pada suatu pembelajaran mungkin dilakukan observasi terlebih dahulu sebelum memunculkan pertanyaan, namun pada pelajaran yang lain mungkin siswa mengajukan pertanyaan terlebih dahulu sebelum melakukan ekperimen dan observasi (Syaifudin, 2018). Aktivitas membangun jaringan juga mungkin dilakukan dalam upaya melakukan eksperimen atau juga mungkin dibutuhkan ketika siswa mendesiminasikan hasil eksperimennya (Sundari, 2017). Berdasarkan pemasalahan diatas maka perlu dilakukan perbaikan pembelajaran agar kreativitas belajar siswa meningkat. Salah satunya dengan menggunakan Model Saintifik pada pembelajaran bahasa Indonesia kelas V. Adapun tujuan dari penelitian ini adalah untuk mengetahui keefektifan model saintifik terhadap kemampuan membaca intensif siswa kelas V.

\section{Metode}

Penelitian ini menggunakan metode kuantitatif. dalam penelitian eksperimen ada perlakuan (treatment). Oleh karena itu, metode eksperimen dapat diartikan sebagai metode penelitian yang digunakan untuk mencari data yang diolah adalah data hasil belajar di kemampuan membaca intensif.

Desain penelitian yang digunakan dalam penelitian ini adalah Pre-Experimental Designs dengan bentuk desain penelitian yang digunakan adalah one-group pretest-posttest design. Validitas penelitian ini adalah validitas soal dan rubrik penilaian. Data dianalisa dengan menggunakan microsoft excel.

\section{Hasil dan Pembahasan}

Hasil nilai pretest sebagai kemampuan awal hasil pemikiran membaca intensif siswa sebelum diberi perlakuan dan nilai postest sebagai kemampuan akhir siswa dalam hal pemikiran membaca intensif setelah diberi perlakuan dengan menggunakan model pembelajaran Saintifik.

Tabel 1. Data hasil nilai pretest dan posttest

\begin{tabular}{cccc}
\hline Jenis Tes & Nilai Tinggi & Nilai Redah & Rata-rata \\
Pretest & 75 & 25 & 47 \\
Posttest & 100 & 50 & 71 \\
\hline
\end{tabular}

Dapat diketahui bahwa hasil belajar sebelum diberi perlakuan nilai pretest menunjukkan rata-rata sebesar 50 Sedangkan setelah diberi perlakuan nilai posttest menunjukkan rata-rata sebesar 72,82. Dari hasil nilai pretest dan posttest menunjukkan nilai rata-rata posttest lebih tinggi daripada nilai pretest. Hal tersebut terjadi karena adanya perlakuan dengan menggunakan model pembelajaran Saintifik dalam kegiatan belajar mengajar yang dilakukan pada saat penelitian. Sehingga terdapat keefektifan dalam keterampilan membaca intensif siswa kelas V.

Sebelum melakukan pengujian hipotesis perlu dilakukan uji persyaratan analisis data terlebih dahulu. Pada uji persyaratan data ini dilakukan pengujian data sebelum perlakuan dan sesudah perlakuan dengan menggunakan uji normalitas. Uji normalitas terdiri dari uji normalitas awal (sebelum diberikan perlakuan) dan uji normalitas akhir (setelah diberikan perlakuan menggunakan model pembelajaran 
Saintifik. Uji normalitas yang digunakan ini bertujuan untuk mengetahui apakah hasil nilai pretest dan hasil nilai posttest siswa berasal dari data yang berdistribusi normal atau tidak. Uji normalitas data dilakukan dengan menggunakan uji Lilliefors.

Tabel 2. Uji normalitas awal dan Uji normalitas akhir

\begin{tabular}{llll}
\hline Jenis Tes & L0 & Ltabel & Keterangan \\
\hline Pretest & 0,1738 & 0,19 & Ho DITERIMA \\
Posttest & 0,1283 & 0,19 & Ho DITERIMA \\
\hline
\end{tabular}

Uji normalitas awal digunakan untuk mengetahui apakah nilai pretest berasal dari sampel yang berdistribusi normal atau tidak. Uji normalitas menggunakan rumus Lilliaefors dengan ketentuan bahwa kelompok berdistribusi normal jika memenuhi kriteria L0 < Ltabel yang diukur pada taraf signifikan 0,05. Untuk melakukan uji normalitas data hasil pretest, maka perlu ditentukan nilai Lhitung yang diambil dari nilai $\left|\mathbf{F}\left(\mathbf{Z}_{\mathbf{i}}\right)-\mathbf{S}\left(\mathbf{Z}_{\mathbf{i}}\right)\right|$ terbesar. hasil perhitungan nilai Pretest dengan jumlah $\mathrm{n}$ sebanyak dua puluh dan taraf signifikan 0,05 di peroleh Ltabel sebesar 0,190 dan L0 atau Lhitung sebesar 0,1738. Karena L0 < Ltabel yaitu 0,1738 $<0,190$ maka H0 diterima. Jadi dapat disimpulkan bahwa artinya sampel berdistribusi normal.

Uji normalitas akhir digunakan untuk mengetahui apakah nilai Posttest berasal dari sampel yang berdistribusi normal atau tidak. Uji normalitas menggunakan rumus Lilliefors dengan ketentuan bahwa kelompok berdistribusi normal jika memenuhi kriteria L0 < Ltabel yang diukur pada taraf signifikan 0,05. hasil perhitungan nilai Posttest dengan jumlah $\mathrm{n}$ sebanyak dua puluh tiga dan taraf signifikan 0,05 diperoleh Ltabel sebesar 0,190 dan L0 atau Lhitung sebesar 0,1283. Karena L0< Ltabel yaitu 0,1283< 0,190 maka H0 diterima. Jadi dapat disimpulkan bahwa artinya sampel berdistribusi normal.

Berdasarkan hasil perhitungan menggunakan microsoft excel pada uji normalitas awal dan uji normalitas akhir menunjukkan bahwa hasil nilai pretest dan posttest siswa mengenai keterampilan membaca intensif siswa pada mata pelajaran bahasa Indonesia berasal dari data yang berdistribusi normal. Kemudian langkah selanjutnya yang dilakukan yaitu pengujian hipotesis menggunakan uji t. Pengujian hipotesis dilakukan untuk mengetahui adanya perbedaan kemampuan akhir siswa dalam hal membaca intensif antara sebelum diberi perlakuan dan kemampuan akhir siswa setelah diberi perlakuan berupa perlakuan menggunakan model pembelajaran Saintifik yang dapat dilihat dari hasil nilai pretest dan posttest siswa. Penelitian ini bertujuan untuk mengetahui seberapa besar keefektifan, maka terlebih dahulu merumuskan hipotesis nihil (HO) dan hipotesis alternative (Ha) (Darmadi, 2011).

Hasil nya menunjukkan bahwa $t_{\text {hitung }}>t_{\text {tabel }}$ atau 9,0507 $>2,021$ dengan taraf signifikan $(\alpha)=$ 0,5 dengan db 39. Hal ini berarti ada perbedaan yang signifikan antara hasiil Pretest dan hasil Posttest. Taraf signifikansi $(\alpha)$ yang digunakan pada pengujian hipotesis ini yaitu $5 \%$, sedangkan uji statistik yang digunakan adalah dengan menggunakan Uji-t . Kriteria penolakan hipotesis nol adalah jika nilai thitung $(t h)$ lebih besar dari $t$ tabel $(\mathrm{tt})$ pada taraf signifikansi $(\alpha) 5 \%$, maka hipotesis nol ditolak (Rata-rata nilai membaca intensif siswa sebelum dan sesudah perlakuan tidak sama) model pembelajaran Saintifik efektif terhadap keterampilan membaca intensif siswa kelas V. Penggunaan model saintifik telah terbukti efektif pada pembelajaran kemampuan membca intensif bahasa Indonesia peserta didik. Pada saat di kelas, peserta didik yang diajar menggunakan model saintifik lebih antusias dan menjadi lebih kritis dalam mengikuti pelajaran daripada peserta didik yang diajar menggunakan metode ceramah. Hasil belajar kemampuan membaca intensif peserta didik yang diajar menggunakan model saintifik, hasilnya lebih baik daripada peserta didik yang diajar menggunakan metode ceramah. Hal ini dikarenakan model saintifik dapat membantu siswa berpikir kritis. Dengan demikian hipotesis alternatif bisa diterima. Berdasarkan penghitungan uji-t diperoleh kesimpulan bahwa terdapat perbedaan yang signifikan kemampuan membaca intensif kelas $\mathrm{V}$ antara nilai pretest (sebelum dilakukan perlakuan) dengan nilai posttest (setelah dilakukan perlakuan).

Tabel 3. Uji-t Pretest Posttest

\begin{tabular}{lllll}
\hline Jenis tes & Mean & $t$ hitung & $\boldsymbol{t}_{\text {tabel }}$ & Keterangan \\
\hline pretest & 47 & 9,0507 & 2,021 & Signifikan \\
\hline posttest & 71 & & & \\
\hline
\end{tabular}


Dari hasil perhitungan diperoleh bahwa $t_{\text {hitung }}=9,0507$. Kemudian dibandingkan dengan harga $t_{\text {tabel }}$ pada $\mathrm{db}=39$ dan taraf signifikansi $=0,05(5 \%)$ didapatkan $t_{\text {tabel }}$ sebesar 2,021. Karena $t_{\text {hitung }}>t_{\text {tabel }}$ yaitu 9,0507 >2,021 maka $\mathrm{H}_{0}$ ditolak dan $\mathrm{H}_{\mathrm{a}}$ diterima. Dari hasil perhitungan diketahui bahwa rata-rata hasil belajar Posttest yaitu 71 yang lebih besar daripada rata-rata hasil belajar Pretest yaitu 47. Dari nilai tersebut dapat diketahui bahwa ada perbedaan antara nilai pretest (sebelum dilakukan perlakuan) dengan nilai posttest (setelah dilakukan perlakuan). Hal ini dapat disimpulkan bahwa $\mathrm{H}_{0}$ ditolak (Rata-rata nilai membaca intensif siswa sebelum dan sesudah perlakuan tidak sama) model pembelajaran Saintifik efektif terhadap kemampuan membaca intensif siswa kelas V.

\section{Simpulan dan Saran}

Berdasarkan hasil analisis data yang telah dilakukan dapat disimpulkan bahwa model pembelajaran Saintifik terbukti efektif terhadap keterampilan membaca intensif siswa kelas V. Hal ini didukung oleh data-data berikut yang dilihat dari: (1) Uji hipotesis penelitian menggunakan uji t diperoleh $\mathrm{t}$ hitung $>\mathrm{t}$ tabel yaitu 9,0507> 2,021 atau rata rata hasil belajar siswa sebelum diberi perlakuan dan sesudah diberi perlakuan tidak sama. (2) Kriteria Ketuntasan Minimal (KKM) dengan rata-rata keterampilan membaca siswa pada saat posttest > pretest. Sebelum diberi perlakuan memiliki rata-rata 47 dan sesudah diberi perlakuan memiliki ratarata 71.

Adapun saran yang dapat diajukan berdasarka hasil penelitian dan pembahasan sebagai berikut: 1) bagi guru, melalui penelitian ini kiranya guru lebih kreatif dalam menentukan model pembelajaran sehingga siswa tidak merasa jenuh dalam pembelajaran. 2) bagi kepala sekolah, diharapkan lebih memberikan ruang kepada guru untuk mengembangkan potensi yang dimiliki guru melalaui FGD. 3) bagi peneleliti lain diharapkan menggunakan penelitian ini sebagai bahan referensi dalam mengembangkan penelitian sejenis.

\section{Daftar Rujukan}

Abidin, Y. (2012). Pembelajaran membaca berbasis pendidikan karakter. Bandung: PT Refika Aditama.

Darmadi, H. (2011). Metodeogi Penelitian Pendidikan. Bandung: Alfabeta.

DePoter, B. (2003). Quantum teaching: mempraktikkan quantum learning di ruang-ruang kelas. Bandung: Kaifa.

Erlina. (2013). Peningkatan Kemahiran Membaca Intensif Melalui Teknik Pembelajaran SQ4-R (Penelitian Tindakan Kelas Pada Mahsiswa Jurusan Pendndidikan Bahasa Arab Fakultas Tarbiyah dan Keguruan IAIN Raden Intan Lampung). Jhalaqa: Islamic Education, 2(1).

Irdawati, Yunidar, \& Darmawan. (2012). Meningkatkan Kemampuan Membaca Permulaan Dengan Menggunakan Media Gambar Kelas 1 di Min Buol. Jurnal Kreatif Tadulako Online, 5(4), 1-14.

Kemendikbud. (2003). Undang-Undang Nomor 20 Tahun 2003 tentang Sistem Pendidikan Nasional (SISDIKNAS). Jakarta: Kementrian Pendidikan dan Kebudayaan.

Khasanah, A., \& Isah Cahyani. (2016). Peningkatan kemampuan membaca pemahaman dengan strategi question answer relationshipS (QAR) pada siswa kelas V sekolah dasar. Jurnal Pedagogik Pendidikan Dasar, 4(2), 161-175.

Munggaran, P. (2014). Penerapan Metode Shared Reading Dalam Pembelajaran Membaca Teks Cerita Anak Pada Siswa Kelas VII SMP. Bahtera Bahasa: Antologi Pendidikan Bahasa dan Sastra Indonesia, No. 2. Penerapan Metode Shared Reading Dalam Pembelajaran Membaca Teks Cerita Anak Pada Siswa Kelas VII SMP.

Rahim, F. (2015). Pengajaran Membaca di Sekolah Dasar. Jakarta: Bumi Aksara.

Resmini, N., \& Juanda. (2007). Pendidikan bahasa dan sastra Indonesia di kelas tinggi. Bandung: UPI Press.

Sani, R. A. (2014). Pembelajaran Saintifik untuk Implementasi Kurikulum. Jakarta: Bumi Aksara.

Sundari, R. (2017). Penggunaan LKS Dengan Pendekatan Saintifik Berbasis Discovery Learning Pada Pembelajaran Larutan Asam Dan Basa. Jurnal Ilmiah Kanderang Tingang. Jurnal Ilmiah Kanderang Tingang, 8(2), 140-152.

Suyitno \& Ngatmini. (2018). Pengantar Praktis Bahasa Indonesia. Yogyakarta: Magnum Pustaka Utama.

Syaifudin, A. (2018). Pengaruh Pendekatan Pembelajaran Saintifik Terhadap HAsil Belajar Peserta Didik 
pada Mata Pelajaran Akidah Akhlak Kelas VIII Reguler di MTS Negeri 1 Blitar. Skripsi, Institut Agama Islam Negeri Tulungagung.

Tarigan, A. (2017). Penerapan Model Pembelajaran Role Playing Untuk Meningkatkan Hasil Belajar Ips Siswa Kelas Iii Sd Negeri 013 Lubuk Kembang Sari Kecamatan Ukui. Primary: Jurnal Pendidikan Guru Sekolah Dasar, 5(3), 102. https://doi.org/10.33578/jpfkip.v5i3.3898 